\title{
Commentary on 'Cultural Diversity Across the Pacific': Samoan Cultural Constructs of Emotion, New Zealand-Born Samoan Youth Suicidal Behaviours, and Culturally Competent Human Services
}

\author{
Jemaima Tiatia \\ Centre for Pacific Studies, The University of Auckland, New Zealand
}

\begin{abstract}
A recent special section on cultural diversity across the Pacific, in this journal, highlighted the need A for greater alignment between human services and cultural diversity in the region. Alignment entails detailing a local context. Samoan cultural constructs of emotion, particularly anger and shame, may precede suicidal behaviours among New Zealand-born (NZ-born) Samoan youth. These behaviours can stem from perceived ruptures in family unity, as youth partly identify with majority norms. A barrier to integration faced by acculturating youth is that the young person either lives with the shame of their offence, or avoids it by taking their life. It seems Samoan cultural constructs of emotion must be considered in effective service delivery for this population. Consistent with the articles in the special section, suicide prevention should focus on developing culturally competent tools tailored for NZ-born Samoan youth, so they may communicate their feelings without fear of disrupting cultural prescriptions and expectations, as well as functioning successfully in both the Samoan and Western worlds. Although the point is discussed in relation to one special population in the Pacific region, it is consistent with an emergent theme in the special section and subsequent commentaries: the need to integrate and acculturate human services.
\end{abstract}

Keywords: suicide prevention, pacific mental health, youth suicide, cultural competency, Samoans, emotion

A recent special section in this journal focused on cultural diversity across the Pacific. A series of three articles by leading psychologists globally considered: (1) regional migration (Furnham, 2010); (2) challenges and opportunities stemming from intercultural integration (Berry, 2010); and (3) the need for psychology itself to be more culturally competent and respectful of diversity (Marsella \& Yamada, 2010). An overarching point across the special section was that (4) one size does not fit all. Commentaries like this are no exception. Detailing a global issue in a local context is the precursor for an informed reflection. This commentary drills down into and illustrates ideas (1)-(4) through the issue of Samoan youth suicide in Aotearoa/New Zealand. Culture shock takes many forms.
Acculturation styles are expressed differently in different cultural settings, and integration may end up distancing the self from older family members whose expectations are more 'traditional'. Acculturation is thus as much a social as individual process - it does not reside in any one person, relationship, or context.

\section{The Issue of Suicide}

On a global scale, suicide is among the top 20 leading causes of death for all ages. Each year, almost one million people die from suicide (World Health Organization, 2011). Suicidal behaviour is complex and may be interpreted along a continuum of severity from suicidal 
ideation, suicide gestures, suicide threats, suicide plans, and suicide attempts, to completed suicide. There are key differences between suicide 'ideators' (people who have contemplated suicide), people who are actual 'attempters', and people who have actually taken their own life ('completers'). For instance, while there are a number of people who think about suicide, very few make an attempt, and of those who make attempts, an even smaller group completes the act (Victorian Government Department of Health, 2010). However, because all three stages of suicidal behaviour are important to consider, this commentary includes all of them as suicide-related behaviour.

\section{Suicide in New Zealand}

In New Zealand suicide is the leading cause of injury resulting in death for people 20 to 74 years of age (Gulliver \& Simpson, 2007). Annually, approximately $500 \mathrm{New}$ Zealanders die by suicide (Ministry of Health, 2012). In 2010, there were 2,825 admissions to hospital (that lasted more than 48 hours) for suicide attempts (Ministry of Health, 2012). Over their lifetime $15.7 \%$ of New Zealanders will experience suicidal ideation, $5.5 \%$ will make a suicide plan and $4.5 \%$ will attempt suicide (Oakley Browne, Wells, \& Scott, 2006).

The public health focus on youth suicide has predominantly been among New Zealand Palagi (European) and Māori (Indigenous, Tangata Whenua, meaning 'people of the land') populations (for a review of the latter see Coupe, 2005). Pacific peoples other than tangata whenua have arguably received less attention. Thus the New Zealand Ministry of Health's suicide prevention strategy for 2006-2016 highlights that mainstream approaches to suicide prevention for Pacific peoples are ineffective on their own. Suicide prevention policies, programs and services targeting Pacific communities require consideration of cultural contexts and Pacific worldviews, particularly around mental health, (Associate Minister of Health, 2006).

\section{Pacific Peoples and Suicide in New Zealand}

In New Zealand, Pacific peoples have had higher rates of mental disorder than the general population (Oakley Browne et al., 2006). Pacific peoples' access to health services were comparatively low compared to the rest of the country's population (Oakley Browne et al., 2006). Ironically, Pacific peoples have higher rates of suicidal ideation, suicide plans, and suicide attempts than all other ethnic groups in New Zealand (Oakley Browne et al., 2006). The 12-month prevalence of suicide attempts was three times the rate of the general New Zealand population (Oakley Browne et al., 2006). Moreover, NZ-born Pacific peoples have higher rates of suicide planning and attempts than Pacific peoples who migrated to New Zealand as adults (Oakley Browne et al., 2006).

\section{Samoan Youth and Suicide in New Zealand}

Nearly one in two people of Pacific backgrounds in New Zealand are of Samoan ethnicity (Statistics New Zealand, 2007). Samoans continue to be highly urbanised (98\%) with $67 \%(87,003)$ living in the Auckland region. The Samoan population is also a youthful population. For example, in 2006, 38\% were under the age of 15 years, and the median age of the Samoan population was 21.1 years in comparison to the overall New Zealand median age of 35.9 years (Statistics New Zealand, 2007). The $2006 \mathrm{New}$ Zealand census indicates that $60 \%$ of the Samoan population were born in New Zealand and that young people were likely to self-identify as belonging to more than one ethnic group; for example, 'New Zealander' and 'Samoan' (Statistics New Zealand, 2006).

During the process of acculturation, one group is typically dominant over others; successful outcomes necessitate mutual accommodation among all groups and individuals living together in a culturally diverse society (Berry, 2012). International studies indicate that conflict with parents increases vulnerability to suicide for youth from ethnic minority populations (Leach, 2006; Leong, Leach, \& Gupta, 2008; Zayas, 2011). Conflict with parents often occurs because youth is seen by the family to be turning their back on traditional norms and values, as they attempt to find their own identity and sense of cultural integration (Duarte-Velez \& Bernal, 2008). With respect to NZ-born Samoans, some youth may identify with both a relational and individual sense of self, which can in addition then create role-confusion and conflict with parents and elders (Bush, Chapman, Drummond, \& Fagaloa, 2009; Tiatia, 2008; Tupuola, 1998). Thus, human services would need to find a way to help Samoan young people and their families respectively 'integrate' and stay 'separate', by preserving tradition first (Berry, 2010). Human services would need to become culturally competent in Samoan traditions (Marsella \& Yamada, 2010).

\section{Cultural Competency Awareness}

The $v a$ or space that relates, is a tapu (sacred) space that connects and holds separate entities and things together in unity (Anae, 2010; Mila-Schaaf, 2006). The $v a$ is a spiritual space in which unity takes precedence over individuality (Autagavaia, 2001; Clayton, 2007). The Samoan proverbial expression teu le va is often used and alludes to cherishing, taking care of, and nurturing the $v a$ in relationships (Wendt, 1996). Recognition of the va occurs when traditional Samoan norms are observed and obeyed. Failure to recognise the $v a$ is to offend the Samoan family and community (Siauane, 2004). This is emphasised in the Samoan social 'golden rule' aua le to'ia le va (do not step over the space/boundary) (Siauane, 2004). Observing, nurturing and maintaining the sacred space and respecting 
relationships is thus pivotal to the fa'asamoa or Samoan way of life and living.

\section{Knowledge}

In Samoan society, the loto (heart, will) is regarded as the source of all emotions (Gerber, 1975; Mageo, 1991). Equally, however, overt expressions of anger by young Samoans are discouraged in order to maintain harmony, to keep young people within cultural boundaries, and to teach young people fa'aaloalo (respect) (Tiatia, 2003). The latter includes self-control, or teu le amio (which means to put one's feelings in order) and to teu le va (take care of the relationship, or $v a$ ). The combination of being expected to do well for the family and self-restraint can create frustration and anger, which then turns inwards (Tiatia, 2003). As one young person put it: 'I wanted to die because of my mum, she just puts too much pressure on me to be the sporty and brainy son and this was my way of telling her to shut-up' (Tiatia, 2003, p. 131).

\section{Skill}

Some youth begin to resent the fa'asamoa (Samoan way) and may mask these feelings for fear of physical reprimand and rejection from the aiga (family) and to avoid showing disrespect to their parents (Tupuola, 1998). In short they teu le $\mathrm{va}$, that is, continue to respect their relationships by observing the sacred space or $v a$. In the words of one NZborn Samoan youth: 'Samoan young people need to talk about when they're upset, like with their family problems, and to learn to go up to whoever they're angry with and talk to them about how they feel, but at the same time I know this is hard for Samoans, but it has to start somewhere' (Tiatia, 2003, p. 163).

\section{Challenges of Balancing Identities}

Within the Samoan social hierarchical structure, for a young person to express anger or resentment towards an elder implies that they consider themselves above their rank (Mageo, 1989). To do so would also be a sign of disrespect and a breach of the va. Thus, due to the predominantly gerontocratic nature of the fa'asamoa (Samoan way) and a tacit restriction on openly expressing any emotional discontent, some youth may find themselves at breaking point:

\begin{abstract}
I tried to write a final letter and my tears were flowing and I was writing in anger. I'd read it and suddenly realised that what I was doing was quite silly, and um, also thinking everybody that I'd be hurting, because there were a few people that I actually wanted to hurt over killing myself like, basically my family, I wanted them to see that the pain that they put me through caused me to do this. (Tiatia, 2003, pp. 131-132)
\end{abstract}

Strategies of withdrawal or abasement are used to demonstrate that as discontented as one is, one still continues to observe cultural boundaries without breaching the $v a$ (White, 1985). For Samoans, if one views all reciprocal relationships with others as sacred, then the relationship will be more valued and nurtured more closely (Anae, 2010). Sadly, it is possible that too many young people would rather engage in suicidal behaviours then harm the relationship. For others, emotional restraint may create a need to vent frustration through other risk-taking behaviours such as drug and alcohol abuse, or adolescent promiscuity (Schoeffel, 1979).

\section{Masking}

$$
\begin{aligned}
& \text {... I fit your plans and schemes for the future. } \\
& \text { You cannot see the real me } \\
& \text { My face is masked with pretence and obedience } \\
& \text { And my smiles tell you that I care } \\
& \text { I have no other choice. (Thaman, 1974, p. 13) }
\end{aligned}
$$

Masking means concealing one's true feelings and is aptly described in an excerpt from the above poem entitled You the Choice of My Parents (Thaman, 1974). This excerpt alludes to traditional parental expectations placed upon a young Pacific woman. Similarly, Tupuola (1998) finds that while some of her Samoan female study participants comply with aiga expectations, that does not necessarily mean they accept them. Tupuola (1998) argues that some mask their inner conflicts in order to fulfil these parental expectations, in the process often negating their yearning for a sense of individual self:

\begin{abstract}
I'm pretty good at hiding my true emotions. I've learned that way before school, before primary school. Everybody expected me to be a happy person, when after getting a hiding they expected me to wipe those tears and you know, be happy again, and if I showed any other emotion like anger I would get another hiding, or if I continued crying. So I guess, yeah, that's where the mask came from, just good at hiding it all. (Tiatia, 2003, p. 153)
\end{abstract}

\section{Recommendations}

NZ-born Samoan youth suicidal behaviours can be partly understood as a question of acculturation, specifically perhaps how youth strive to 'integrate' one identity with another while continuing to respect family traditions that may lean somewhat more towards 'separation' (Berry, 2010). This can create intolerable acculturative strain. Culturally competent services are required so that Samoan youth can readily find providers in whom they can trust and who understand what it is to be a NZ-born Samoan young person in New Zealand (Tiatia, 2003). Any health approach involving Samoans should emphasise interpersonal relations, building trust and rapport between individuals, families and health professionals (Suaalii-Sauni et al., 2009). The need for such sensitivities was highlighted in Marsella and Yamada (2010). Crucially too, the type and level of acculturation of Samoan youth clients should be assessed by culturally competent health professionals (Tiatia, 2008). In that regard, 'A true user-oriented service, the benchmark of future mental health services, offers choice and a mixed economy of care suited to the needs of 
the individual and flexible enough to accommodate difference' (Bhui \& Sashidharan, 2003).

\section{Acknowledgements}

This commentary is based on Health Research Council of New Zealand funded doctoral and post-doctoral research. The author also wishes to acknowledge Dr Melani Anae from the University of Auckland's, Centre for Pacific Studies and David Lui for their contribution to this article.

\section{References}

Anae, M. (2010). Research for better Pacific schooling in New Zealand: Teu le va - a Samoan perspective. MAI Review, 1, 1-24. Retrieved from http://review.mai.ac. nz/index.php/MR/article/view/298/395

Associate Minister of Health. (2006). The New Zealand suicide prevention strategy 2006-2016 (pp. 1-30). Wellington, New Zealand: Ministry of Health.

Autagavaia, M. (2001). Social work with Pacific Island communities. In M. Connolly (Ed.), New Zealand social work: Contexts and practice (pp. 72-84). Auckland, New Zealand: Oxford University Press.

Berry, J.W. (2010). Intercultural relations and acculturation in the Pacific region. [Special Section: Cultural Diversity across the Pacific]. Journal of Pacific Rim Psychology, 4(2), 95-102.

Berry, J.W. (2012). Intercultural relations and acculturation in the Pacific region. Journal of Pacific Rim Psychology, 4(2), 95-102.

Bhui, K., \& Sashidharan, S.P. (2003). Should there be separate psychiatric services for ethnic minority groups? The British Journal of Psychiatry, 182, 10-12.

Bush, A., Chapman, F., Drummond, M., \& Fagaloa, T. (2009). Development of a child, adolescent and family mental health service for Pacific young people in Aotearoa/New Zealand. Pacific Health Dialog, 15(1), 138-146.

Clayton, L. (2007). Patterns and motifs in the va: A Samoan concept of space. (Unpublished Masters thesis). Auckland University of Technology, New Zealand.

Coupe, N. (2005). Whakamomori: Māori suicideprevention. Doctoral disseration, Massey University, New Zealand.

Duarte-Velez, Y.M., \& Bernal, G. (2008). Suicide risk in Latino and Latina adolescents. Suicide among racial and ethnic minority groups (pp. 81-115). New York: Routledge.

Furnham, A. (2010). Culture shock: Literature review, personal statement and relevance for the South Pacific. [Special Section: Cultural Diversity across the Pacific]. Journal of Pacific Rim Psychology, 4(2), 87-94.

Gerber, E. (1975). The cultural patterning of emotions in Samoa. (Unpublished doctoral dissertation). University of California, CA.

Gulliver, P.J., \& Simpson, J.C. (2007). Cause of injury by age (Fact sheet 39). Dunedin, New Zealand: Injury Prevention Research Unit, University of Otago.

Leach, M.M. (2006). Cultural diversity and suicide: Ethnic, religious, gender, and sexual orientation perspectives. New York: The Haworth Press.
Leong, F.T.L., Leach, M.M., \& Gupta, A. (2008). Suicide among Asian Americans: A critical review with research recommendations. In F.T.L. Leong \& M.M. Leach (Eds.), Suicide among racial and ethnic minority groups (pp. 117-141). New York: Routledge.

Mageo, J. (1989). Ferocious is the centipede: A study of the significance of eating and speaking in Samoa. Ethos, 17(4), 387-427.

Mageo, J. (1991). Samoan moral discourse and the loto. American Anthropologist, 93, 405-420.

Marsella, A.J., \& Yamada, A.M. (2010). Culture and psychopathology: Foundations, issues, direction. [Special Section: Cultural Diversity Across the Pacific]. Journal of Pacific Rim Psychology, 4(2), 103-115.

Mila-Schaaf, K. (2006). Va-centred social work: Possibilities for a Pacific approach to social work practice. Tu Mau II Social Work Review, XVIII, 8-13.

Ministry of Health. (2012). Suicide facts: Deaths and intentional self-harm hospitalisations 2010. Wellington, New Zealand: Author.

Oakley Browne M., Wells J.E., \& Scott K.M. (Eds.). (2006). Te rau hinengaro: The New Zealand mental health survey. Wellington, New Zealand: Ministry of Health.

Schoeffel, P. (1979). Daughters of Sina: A study of gender, status and power in Western Samoa. (Unpublished doctoral disseration). Australian National University, Australia.

Siauane, L.L. (2004). Fa'asamoa: A look at the evolution of the fa'asamoa in Christchurch. (Unpublished Masters thesis). University of Canterbury, New Zealand.

Statistics New Zealand. (2006). QuickStats about Pacific peoples. Retrieved from http://www.stats.govt.nz/Census/ 2006CensusHomePage/QuickStats/quickstats-about-asubject/pacific-peoples.aspx

Statistics New Zealand. (2007). Samoan people in New Zealand: 2006. Wellington, New Zealand: Author.

Suaalii-Sauni, T., Wheeler, A., Saafi, E., Agnew, F., Warren, H., Erick, M., \& Hingano, T. (2009). Exploration of Pacific perspectives of Pacific models of mental health service delivery in New Zealand. Pacific Health Dialog, 15(1), 1827.

Thaman, K.H. (1974). You, the choice of my parents. Suva, Fiji: Mana Publications.

Tiatia, J. (2003). Reasons to live: NZ-born Samoan young people's responses to suicidal behaviours. (Unpublished doctoral dissertation). The University of Auckland, New Zealand.

Tiatia, J. (2008). Pacific cultural competencies: A literature review. Wellington: Ministry of Health.

Tupuola, A.M. (1998). Adolescence: Myth or reality for 'Samoan' women? Beyond stage-like toward shifting boundaries and identities. (Unpublished doctoral dissertation). Victoria University, New Zealand.

Victorian Government Department of Health. (2010). Suicide risk assessment and management: A systematic evidence review for the clinical practice guidelines for emergency departments and mental health services project (pp. 1-86). Melbourne, Australia: Author. 
Wendt, A. (1996). Tatauing the post-colonial body. Span, 42(43), 15-29. Retrieved from http://www.nzepc.auckland. ac.nz/authors/wendt/tatauing.asp

White, G. (1985). Suicide and culture: Island views. Paper presented at the Culture, Youth and Suicide in the Pacific, Honolulu.
World Health Organization. (2011). Mental health: Suicide prevention Retrieved from http://www.who.int/mental_ health/prevention/en/

Zayas, L.H. (2011). Latinas attempting suicide: When cultures, families, and daughters collide. New York: Oxford University Press. 